\title{
Na Maré Profunda: infraestruturas midiáticas e o oceano animado.
}

\author{
Ruy Cézar Campos Figueiredo¹, Erick Felinto²
}

Resumo: A artista franco-guianense Tabita Rezaire lançou em 2017 sua obra Na Maré Profunda, exposta no ano de 2018 no Brasil na exposição Campos de Invisibilidade. Aqui serão articuladas relações entre sua obra, suas reflexões e questões teóricas que permeiam a arte e o pensamento sobre as mídias no contexto da pós-internet, resultando em um texto que promove um encontro entre infraestruturas midiáticas, estudos africanos, tecnologia, animismo e epistemologia.

Palavras-Chaves: Infraestruturas midiáticas. Epistemologia. Pós-Internet.

\section{Deep Down Tidal: media infrastructures and the animated ocean.}

\begin{abstract}
French-Guinean artist Tabita Rezaire released in 2017 her work Deep Down Tidal, part of the exhibition Fields of Invisibility which occurred in Brazil late 2018. This paper will articulate relations between the videoinstallation, her thoughts and theoretical issues that permeate the art and thought in post-internet context, resulting in a text that promotes the meeting of African studies, media infrastructures, technology, animism and epistemology.

Keywords: Media infrastructures. Epistemology. Post-internet.
\end{abstract}

\footnotetext{
${ }^{1}$ Doutorando em Tecnologias da Comunicação e Cultura- Universidade do Estado do Rio de Janeiro - UERJ. Mestre em Artes e Processo de Criação: Poéticas Contemporâneas na Universidade Federal do Ceará - UFC. Bacharel em Audiovisual e Novas Mídias na Universidade de Fortaleza - UNIFOR.

E-mail: czr.campos@gmail.com; ORCID: https://orcid.org/0000-0001-8339-6634

2 Professor associado do programa de pós-graduação em comunicação da UERJ e pesquisador do CNPq. Em sua produção bibliográfica, destacam-se A Religião das Máquinas: Ensaios sobre o Imaginário da Cibercultura (Sulina, 2005) e O Explorador de Abismos: Vilém Flusser e o Pós-Humanismo (Paulus, com Lucia Santaella, 2012). Além de diversos livros e artigos sobre cibercultura, cinema, estudos literários e teoria da comunicação, Felinto foi colaborador e tradutor (alemão-português) da obra Flusseriana, o dicionário trilíngue de conceitos de Vilém Flusser editado pelo Centro de Arte-Mídia de Karlsruhe (Flusseriana, Univocal, 2015)

E-mail: erickfelinto@gmail.com; ORCID: https://orcid.org/0000-0003-2613-5774
} 


\section{Introdução}

Artistas e pesquisadores têm, recentemente, impulsionado uma onda de atenção crítica sobre relações entre cultura de rede e infraestruturas midiáticas. Esse impulso não se dá ao acaso e tem colaborado importantemente para que se possa evidenciar complexidades de camadas ainda pouco exploradas da experiência midiática contemporânea. Mais que fomentar respostas, o processo vem engendrando novas perguntas às questões que se têm lançado ao se perscrutar relações entre mídia e tecnologia na contemporaneidade a partir de um foco infraestrutural.

A maior liberdade especulativa e metodológica no fazer artístico possibilita que artistas incidam sobre os assuntos que abordam desde posições peculiares, invocando não apenas as linhas lógicas de um texto escrito para produzir conhecimento, mas também outras affordances epistemológicas $^{3}$ que estão embutidas nas práticas artísticas contemporâneas. O conhecimento que se fermenta na teia de relações vetorizadas em um trabalho de arte a tornam uma área onde o saber pode emergir escapando da mera objetividade e linearidade científica.

Nesse sentido, situa-se aqui a videoinstalação Na Maré Profunda (Deep Down Tidal), da artista franco-guianense Tabita Rezaire, que nos últimos anos viveu e desenvolveu sua poética entre África do Sul e a Guiana Francesa. Alguns trechos da vídeoinstalação serão destacados para se dialogar com autores relacionados aos estudos de mídia e estudos africanos, atravessando temas como a água na condição de meio elementar, animismo, epistemologia, decolonização e a infraestrutura de cabos submarinos. No Brasil, tal obra esteve exposta na exposição Campos de Invisibilidade, que ocorreu entre o final de 2018 e o início de

\footnotetext{
${ }^{3}$ Utiliza-se esse termo tomando como base a valorização que as metodologias artísticas tomam nos estudos sobre as ecologias das mídias, por incorporarem distintas materialidades e explorarem as affordances dos objetos de maneiras especulativas e experimentais, capazes de falar sobre a materialidade das realidades do hardware, software e das infraestruturas que possibilitam as mídias existirem. Essa capacidade advém, também, do fato de que nesses métodos estão embutidos uma "Ionga cascata" de relações materiais recorrentes na história das práticas artísticas. Parikka (2015) destaca como uma compreensão ecológica das mídias tem como centralidade as noções de materialidade e affordance, que se demonstram potentes para desterritorializar uma lógica humanista das mídias, ensejando abordagens que se colocam para fora do corpo humano e passam a olhar para o não-humano como parte de um emaranhado de agências.
} 
2019 no Sesc Belenzinho, em São Paulo, com curadoria de Cláudio Bueno e Lígia Nobre.

\section{Arte pós-internet}

O vídeo tem duração de 00:18:40 e é exposto em uma grande tela panorâmica curvada. A primeira imagem que aparece é a de um ícone de sinal de wi-fi sobreposto pelo desenho de uma mão com a cor de pele branca ao lado de sua réplica em azul transparente; a mão branca segura um telefone celular e no plano de fundo vemos o espaço sideral repleto de estrelas. Após o ícone de wi-fi sumir, aparece sobreposta ao espaço sideral uma jovem negra segurando um telefone celular no interior de uma nuvem. A jovem conversa com uma amiga, em inglês, sobre seu sentimento de frustração diante do racismo que sofre por parte dos algoritmos do Facebook. O plano de fundo muda, então, do espaço estrelar para um oceano digital em movimento, sobre o qual diversas telas de busca de imagens do Google passam a se sobrepor, demonstrando resultados que revelam estereótipos racistas embutidos no processamento algorítmico das imagens. Em voz-over, escutamos a jovem falar sobre racismo on-line e consumo de dados.

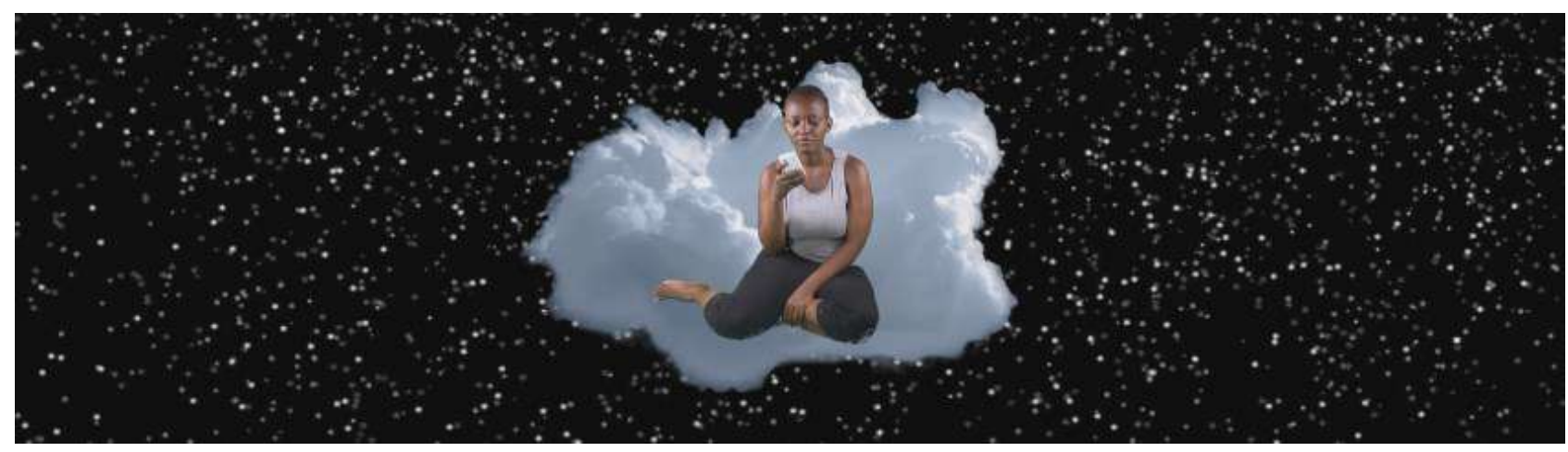

Figura 1 Em tal trecho destacado do primeiro minuto de Na Maré Profunda, vemos Frame de Na Maré Profunda. Fonte: Cortesia da Artista claramente uma disposição a se articular uma experiência peculiar em torno da rede digital, suas metáforas atmosféricas (nuvem), galácticas (ciberespaço) e oceânicas (navegação), o uso da atenção como uma fonte de lucro pelas redes sociais, as entranhas entre o espaço off-line e o espaço on-line, além do corpo negro diante das decisões algorítmicas. Também se percebe o uso de uma retórica visual de propaganda, design gráfico, banco de imagens, marcas corporativas, merchandising visual e ferramentas de softwares comerciais(CHRISTOU \& HAZAS, 2005, p. 8; 
trad. nossa), no que se abre uma reflexão sobre o que pode ser a Internet, suas aplicações, serviços, culturas, sociedades, limitações etc.

A combinação entre o tema e essa retórica visual se encaixa no que Christou e Hazas (2005, p. 8-9) elencam como característico da postinternet art, um termo controverso usado primeiramente em 2006 pela artista e curadora Marisa Olson, como um desdobramento direto da expressão net.art, que advém da década de 1990. Tal expressão se refere a trabalhos artísticos que se utilizavam da Internet não só como um meio de transmissão, mas também como uma plataforma para lidar com temas e questões características da então ainda emergente cultura de rede.

[...] arte que é definida de maneira controversa como pós-internet, isto é, conscientemente criada em um contexto que assume a centralidade da rede, e que geralmente leva em consideração desde os bits físicos até as ramificações sociais da internet. Desde a natureza mutável da imagem até a circulação de objetos culturais, da política de participação para novas percepções sobre materialidade, as intervenções apresentadas por essa rubrica buscam nada mais que a redefinição da arte para a era da internet. (PECKHAM \& ARCHEY, 2015, p. 8-9; trad. nossa)

O prefixo "pós" de pós-internet, todavia, é razão de controvérsias: seu emprego significa que na arte se postula hoje a morte da Internet? Too much world: Is the Internet dead?, de 2013, é um ensaio influente de Hito Steyerl, artista e co-fundadora do Research Center for Proxy Politics na Universität der Künste Berlin, e que se tornou na década de 2010 um dos nomes mais reconhecidos na discussão sobre a vida e a arte com a cultura de rede. Sua resposta para a controvérsia não está na confirmação da morte da Internet, que conotaria um sentido temporal para o prefixo pós de "pós-internet", mas na afirmação de que a Internet entrou em um processo distinto do que a marcou inicialmente, deixando de ser uma possibilidade, um futuro em aberto, para ser uma superpotência que captura inteiramente a imaginação, atenção e produtividade de mais pessoas do que nunca, ubiquamente.

Estar ubíqua, todavia, não significa estar disponível para todos igualmente. No minuto destacado do vídeo de Rezaire, depara-se com elementos suficientes para pensar que a conexão em rede deve ser situada também a partir da experiência corporificada daqueles que esbarram com algoritmos racistas e que, ainda que consumam dados, o fazem a partir de escolhas econômicas onde a balança distribui Internet, comida e vestimenta em um peso de custo fundamental. 
Prosseguindo a análise: a jovem negra sentada sobreposta à nuvem que flutua no espaço sideral diz em sua conversa por telefone com uma amiga:

Olha, na verdade, não tô bem. Essa coisa da internet, do Facebook. Sim, sabe. Não amiga, eu tipo que postei algo sobre as pessoas brancas falando que elas deveriam devolver a nossa terra, sabe? Sim. E eles me baniram do Facebook, acredita? (REZAIRE, 2017)

No que segue do vídeo, há um corte na imagem e vemos a inserção de um fundo oceânico noturno e tempestuoso processado digitalmente, com o aparecimento de uma frase em formato estilizado em softwares de processamento de texto: Essa ligação telefônica foi trazida para você pelo COLONIALISMO ELETRÔNICO. Escutamos o desenrolar da conversa:

[voice-over]: Eles tão tentando nos deixar burras ou algo assim, não sei. Isso é, hum..., racismo, isso realmente não é bom. É como se não estivessem nos tratando com igualdade. Não estão nos tratando como seres humanos... Ah, e essa coisa dos dados. Isso realmente precisa acabar, sabe?! Bom, sim, porque nós ficamos gastando nosso dinheiro comprando dados em vez de comprar bebidas ou um vestido, ou pão, ou algo assim. (REZAIRE, 2017)

Pode-se pensar, assim, Na Maré Profunda como situado entre diversas características da arte pós-internet: por explorar esteticamente o digital, invocando associações entre suas metáforas espaciais e imagens geradas por meio de processamento 3D sobrepostas com imagens apropriadas e produzidas a partir de navegações on-line, mas mais peculiarmente por protagonizar uma experiência corporificada negra em relação aos dados e à cultura da rede. Essa condição situacional de uma corporificação online vai ganhar, na continuação do vídeo, outras nuances conforme se discutem questões infraestruturais da rede e a relação dessas infraestruturas com práticas coloniais do passado e do presente, navegando com isso para as relações epistemologicamente cinzentas entre oceano, memória e tecnologias de comunicação.

\section{Animando o oceano no pensamento midiático}

Parte da proposta do presente artigo é costurar relações entre questões que emergem intensamente na videoinstalação de Tabita Rezaire e que também têm emergido, de distintas maneiras e a partir de variadas influências teóricas, no pensamento midiático contemporâneo. Apostase, assim, que há um potencial peculiar na elaboração do pensamento por meio da retroalimentação entre modos de falar e produzir artisticamente 
e modos de falar e produzir academicamente, para além do próprio campo de estudos das artes.

No presente tópico, toca-se em uma discussão que envolve tecnologias e infraestruturas de comunicação, imaginário oceânico e animismo, conforme levantado pela própria Rezaire não só em sua videoinstalação, mas nas suas próprias reflexões em torno do tema:

As espiritualidades africanas e indígenas possuem um relacionamento com a água como uma interface entre o mundo material e espiritual. Nossa economia global também depende da água para compartilhar e disseminar sua rede de informação. Tanto um quanto o outro usam a água como um campo e uma membrana para comunicação. [...] A água também é uma tecnologia assim como a internet pode ser uma tecnologia de informação e comunicação. (REZAIRE, 2018; trad. nossa)

O texto acima é uma transcrição de um trecho da fala Cura Decolonial: Tecnologia, Espiritualidade e o Erótico de Tabita Rezaire no Encontro Campos de Invisibilidade, que ocorreu em São Paulo em novembro de 2018. É uma fala que articula um argumento distribuído em sua vídeoinstalação, destacando-se aqui um trecho localizado entre os 11 minutos, onde vemos as seguintes frases aparecerem de modo fragmentado com uma estética de webart do software Word:

A ÁGUA LEMBRA. TUDO QUE FOI. TUDO QUE SERÁ. A água copia informação. A água transporta dados. A água grava e circula. A água é uma interface comunicacional. A água é tecnologia. Nós vamos baixar os seus segredos. A ÁGUA É VIDA. Cidades submersas. Navegações esquecidas. Migrações deletadas. Rede transoceânica. Amnésia manufaturada. Passado escondido do espaço. Civilização aquática. Bordas marítimas - costa continental - mar territorial - propriedade do oceano. Desrespeito. (REZAIRE, 2017)

Curiosamente, a abordagem adotada por Rezaire vai a contrapelo das noções que o pensamento ocidental tradicionalmente relacionou ao ambiente aquático. Como afirma Carl Schmitt, em sua clássica obra $O$ Nomos da Terra, "no mar aberto não existem limites, fronteiras, locais consagrados, orientações sacras, nem lei nem propriedade" (2006, p. 43). Essa é uma das razões pelas quais o pensamento grego, especialmente em Platão, nutria certa desconfiança em relação aos mares. Bernhard Siegert insiste nesse pânico marítimo do platonismo, dado que "a água é o meio das misturas", e nela não se pode produzir nenhum rastro ou inscrição (2003, p. 36). 
Para Rezaire, porém, a "água carrega dados" e "copia informação". É, desse modo, um medium de ordem tecnológica. Talvez, na verdade, um domínio no qual o natural e o artificial podem convergir. Nesse sentido, não obstante o contraste assinalado acima, Siegert e Rezaire entram em concordância. Afinal, segundo o primeiro, foi do "espaço elementar (Elementarraum) do mar que derivou o espaço elementar do digital e dos meios" (2003, p. 19).

As imagens que vemos enquanto tal texto vai aparecendo são imagens sobrepostas do oceano, de uma molécula de DNA, cabos de fibra óptica, um homem dançando com uma cobra, sinais de wi-fi cobertos de água, uma sereia digital, um monstro tentacular em um gêiser, ruínas arqueológicas subaquáticas, peixes e polvos digitais.

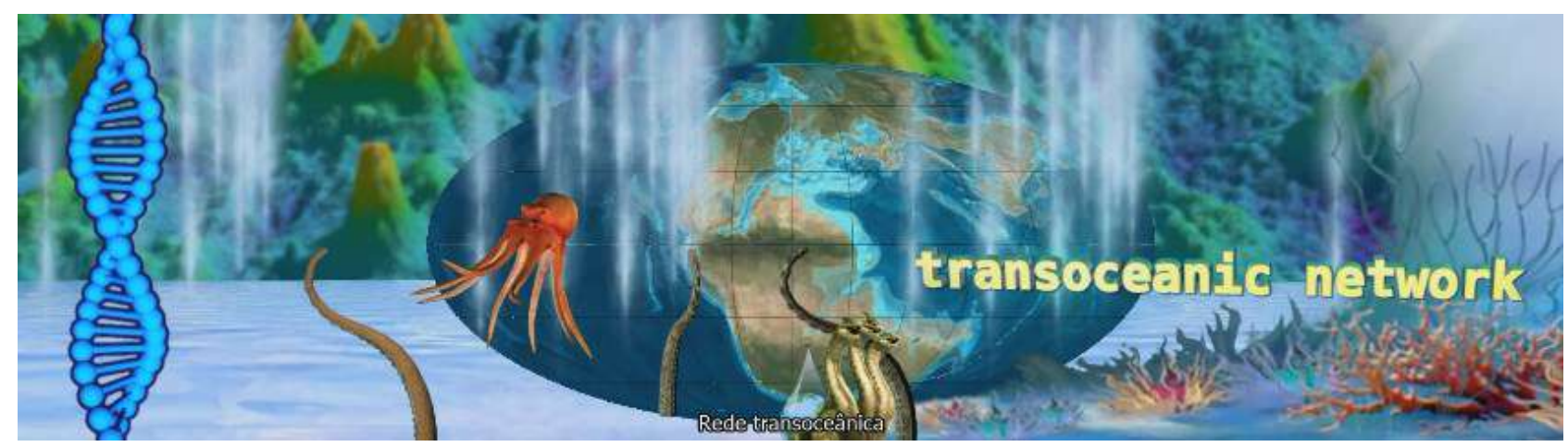

Figura 2 Ao estabelecer conexões entre a infraestrutura de cabos submarinos e o Frame de Na Maré Profunda. Fonte: Cortesia oceano como uma mídia comunicacional, Rezaire converge parcialmente da Artista com conexões que também têm sido feitas por teóricos que se referem constantemente aos cabos submarinos de fibra óptica quando vão discutir temas emergentes na relação entre teoria das mídias e o oceano. John Durham Peters, por exemplo, escreve que para se entender sobre mídia, um conceito anfíbio ${ }^{4}$, devemos começar não no solo, mas no mar (PETERS, 2015, p. 76), referindo-se à Internet como um tipo de inteligência extra-humana se espalhando através de um meio oceânico.

\footnotetext{
4 Para Peters, o conceito de mídia é anfíbio no entremeio de organismo e artificio, e a zoologia seria teoria das mídias sem saber, um livro aberto de estudos comparados de mídia, conforme os organismos vivos nos revelam um assustador e comicamente diverso espectro morfológico e funcional de configurações historicamente sedimentadas de soluções para problemas da existência, que os humanos modulam através de técnicas e tecnologia. Os organismos vivos seriam um catálogo de aparatos técnicos, repletos de mídias esperando outras mídias as revelarem.
} 
Nicole Starosielski, uma influência mais explícita no trabalho de Rezaire e que possui uma pesquisa extremamente instigante sobre os cabos submarinos que permitem a Internet existir como a conhecemos, escreve em um capítulo de seu livro The Undersea Network (2015) especificamente sobre como a oceanografia sempre contou com as tecnologias e infraestruturas de cabos submarinos para desenvolver sua epistemologia do oceano.

Também a relação entre o imaginário oceânico conectando cabos submarinos com espiritualidades aquáticas é um tema que ao menos uma vez emergiu, especificamente na área da Antropologia, através de Braun (2015), em seu estudo de caso sobre um grupo de trabalhadores chineses que viralizaram na Internet congolesa o registro de uma "sereia", uma Mami Wata da mitologia Kinshasa ${ }^{5}$, encontrada no Rio Congo enquanto instalavam um cabo de fibra óptica. O próprio título do artigo de Braun, Cyber Siren: What Mami Wata Reveals About the Internet and Chinese presence in Kinshasa, sugere Mami Wata, ou o imaginário em torno dela, como agente epistemológico sobre a Internet e a presença chinesa no Congo.

Não é surpresa, assim, que sejam invocadas por Rezaire imagens de alteridades radicais habitantes do imaginário marítimo-aquático, como sereias e também monstros tentaculares. A monstruosidade tentacular como uma força epistemológica, por exemplo, tem se tornado objeto de atenção no pensamento midiático a partir da obra Vampyroteuthis Infernalis de Vilém Flusser. Em Flusser, encontramos um pensador que, conforme Felinto (2018, p. 121), sugere como o homem encontra seu destino histórico-tecnológico na criatura das profundezas marinhas e nos abismos aquáticos em que habita. O filósofo tcheco-brasileiro desenvolve tal obra fluindo entre a ficção e a ciência, mostrando-nos como tecnologias - "emissões bioluminescentes e jatos de tinta" - de um monstro das profundezas marinhas encontram seu paralelo em nossos aparatos tecnológicos, criando uma obra que enseja uma epistemologia midiática e tecnológica pautada em um engajamento com o

\footnotetext{
5 A Mami Wata é uma espiritualidade aquática pré-colonial de personificações diversas, mas comumente associada com a imagem da sereia e de uma bela mulher. No artigo de Braun, ela traz referências que afirmam que Mami Wata como uma metáfora para uma alteridade em termos de gênero, exotismo e modernidade, e que no caso específico analisado por Braun tem uma forma mais material e horrenda de uma cobra ao mesmo tempo que uma forma imaterial no espaço digital.
} 
"inteiramente outro". Ou seja, com um lugar da alteridade repleto de potencialidades epistemológicas, que seria o próprio oceano, real e simbólico (FELINTO, 2018, p. 122).

E o oceano é, antes de tudo, água. Relacionar-se com esse elemento o considerando uma tecnologia da comunicação, como sugere Rezaire, é uma atitude ancestral que tem buscado meios também de se fundamentar não só nos termos das cosmovisões ameríndias e africanas, mas também nos termos da ciência ocidental.

Novamente, John Durham Peters é interessante para pensar como se chega a teorizar, atualmente, jatos de tinta de criaturas submarinas ou a própria água enquanto tecnologias. Como filósofo refletindo sobre tecnologias midiáticas a partir de Heidegger e dos cetáceos, ele vai postular que há inteligência em todas as formas de matéria: uma inteligência que, todavia, não se comunica por si mesma ao nosso modo humano de inteligibilidade, mas que ainda assim se constitui como uma inteligência acumulada em milhões de anos, mais inteligente que todos os artigos científicos já publicados (PETERS, 2015, p. 113).

A alteridade da natureza para a cultura é revelada através da cultura de cada elemento ou espécie que se põe sob foco crítico, sob questão. Conforme Peters, as criaturas vivas são soluções historicamente ricas para nossas experiências de interação com os ambientes; são técnicas que esperam outras técnicas as revelarem. A ciência está sempre atrás dessa natureza, tornando inteligível para humanos o que sempre esteve lá. A natureza conhece, todavia, diferentemente do humano:

Por si mesma, a natureza se sobressai como práxis (é uma incansável solucionadora de problemas), como poiésis (é a maior de todos makers), mas falta em theória. A técnica faz a theória possível. A natureza já sabe como fazer coisas incríveis - mas essas coisas só parecem milagrosas por não sabermos ainda como as fazermos (PETERS, 2015, p. 113; trad. nossa)

A chave, todavia, para pensar o oceano como uma tecnologia ou como agente talvez não esteja melhor posta na zoologia dos cetáceos, mas na microbiologia, e não é à toa que flutua na imagem do vídeo de Tabita Rezaire um DNA. Luc Montagnier, galardoado Nobel de Fisiologia em 2008 por suas descobertas sobre HIV, revelou que certas sequencias de DNA de vírus e bactérias dissolvidas em água geram sinais eletromagnéticos e que tais sequencias podiam ser reconstituídas a partir desse sinal, reforçando um campo de especulações científicas em torno das habilidades comunicativas das partículas de água. 
Stefan Helmreich (2009), por vez, faz uma espécie de estudo etnográfico sobre uma nova geração de biólogos marinhos que passaram a ver o mar como dotado de um certo ânimo a partir do estudo genético de micróbios. Helmreich discute as nuances epistemológicas da proposição do cientista Craig Verter (conhecido por ter acelerado a decodificação do genoma humano) de decodificar o "genoma do oceano", sendo o título do artigo de Helmreich exatamente: Como o oceano ganhou o seu genoma?.

Não está muito longe, também, o trabalho de Bernd-Helmut Kröplin, diretor do Institute for Statics and Dynamics of Aerospace Constructions da Universidade de Stuttgart (onde construiu a primeira aeronave movida a energia solar), entre 1988 e 2010 , e que passou a pesquisar sobre a água juntamente com a artista Rüth Kubler. O interesse da dupla era saber se e como pequenos níveis de radiação eletromagnética a afetam, investigando a transferência de informação entre suas moléculas. Os resultados de sua pesquisa o fizeram imaginar, assim, o que é possível através da constatação de que a água possui memória e que suas moléculas podem se comunicar (KRÖPLIN, 2016, p. 10).

A obra de Tabita Rezaire opera esses dados não a partir apenas de um imaginário pautado no pensamento racional científico, mas também a partir do domínio fluido e livre de um imaginário audiovisual africano, habitando uma zona cinzenta ou um interstício entre os domínios da realidade, do pensamento e da linguagem pós-internet. Intelectualizar sua abordagem decolonial sobre água, tomando como referências cientistas do norte global pode ser um equívoco desnecessário, mas que aqui parece interessante por abrir diálogos, pontuando sua posição significativa no debate.

Também engatilha uma discussão sobre o animismo na contemporaneidade, aproveitando para evocar as contradições em torno desse fenômeno.

O animismo tem início nas ciências quando o físico e químico Georg Erns Stahl cunhou o termo para descrever a especificidade da matéria viva em face das coisas não vivas (BORCK, 2012, n.p.). Seu sentido moderno e mais popular, todavia, é relacionado ao antropólogo Edward Burnett Tylor, que o usou para caracterizar uma visão de mundo não discriminante entre as matérias vivas e as não vivas, e que acredita em uma animação universal da natureza.

O professor de Estudos Africanos da Universidade de Cape Town, Harry Garuba (2012, n.p.), argumenta que o animismo que antes era 
considerado como um erro, subdesenvolvimento cognitivo ou falha epistemológica, agora tem crescentemente ganhado atenção discursiva e se tornado objeto de investigação intelectual, além de plataforma de ação política:

O que levou a esse reconhecimento foi que após o trabalho dos movimentos ambientais e ecológicos que crescentemente passaram a invocar compreensões animistas do mundo a partir de comunidades indígenas, das epistemologias relativistas pós-modernas, do espiritualismo New Age, e da fala de antropólogos contemporâneos sobre epistemologias relacionais e diferentes concepções de personificação através da cultura, parece que a fronteira entre Natureza e Sociedade, o mundo dos objetos e dos sujeitos, o mundo material e aquele da agência e dos significados simbólicos, é menos certa do que o projeto modernista decretou. Esses desenvolvimentos recentes podem coletivamente ou em conjunção ser ditos como responsáveis pelo retorno do animismo para a atenção discursiva. Esse interesse, todavia, abre uma significante série de questões. (GARUBA, 2012, n.p.; trad. nossa)

Garuba sugere que o animismo seria assim um "outro espectral" que ao mesmo tempo constitui e assombra a episteme moderna, usado no contexto do modernismo colonialista como um receptáculo metafórico para tudo que seria uma negação da modernidade. Se o conhecimento científico das ciências não-humanas se devota ao estudo do mundo material através de protocolos metodológicos e práticas que primeiramente envolvem a limpeza dos objetos de todos traços simbólicos de significado atribuído pelos "outros", Garuba argumenta que a própria identidade da ordem de conhecimento científico se constitui através do que exclui, tanto em termos de normas, quanto em termos de discurso e protocolos de enunciação. Sua aproximação com modos de conhecer animistas se refere, assim, a uma tomada de posição epistemológica em relação ao mundo que se caracteriza da seguinte maneira:

Se o objeto da epistemologia moderna é um esquema totalizante de essências separadas, abordadas idealmente desde um ponto de vista separado, o objeto desse conhecimento animista é a compreensão da relacionabilidade desde um ponto de vista relacionado, dentro do horizonte cambiante do espectador em relação. [...] Contra o "penso, logo existo" está o "eu me relaciono, portanto sou" e o "eu sei conforme me relaciono". Contra o enquadramento materialista do ambiente como coisas discretas está o enquadramento relacional do ambiente como relacionabilidade aninhada [nested relatedness]. Ambos são reais e válidos. Cada um tem seus limites e forças. (NAVEH \& BIRD-DAVID, 2013, p. 35; trad. nossa) 
A complexificação do problema trazida pelo autor, todavia, é que o animismo que emerge na cultura científica contemporânea é um animismo voltado ao estabelecimento de novos constructos e paradigmas ocidentais, com o Ocidente permanecendo como o sujeito teórico soberano do conhecimento, enquanto a experiência vivida das alteridades animistas ainda está para ser disciplinada em conhecimento formal:

\begin{abstract}
Se a nova convergência de interesse em animismo for trazer alguma vantagem para aqueles do outro lado da modernidade, é aqui que deveríamos começar com uma concepção de tempo que rejeita a linearidade e reconhece o complexo emaranhado de diferentes temporalidades, formações discursivas discordantes e distintas, bem como diferentes perspectivas epistemológicas existindo no mesmo tempo histórico. E aí deveríamos buscar por uma linguagem para representar esse conhecimento. (GARUBA, 2012, n.p.; trad. nossa)
\end{abstract}

Coloca-se, aí, na chamada para uma outra concepção de tempo e modo de se relacionar com tal, um ponto interessante para o entrecruzamento entre pensamento decolonial e certas abordagens sobre o tempo vinculadas à arqueologia das mídias. Nesse ponto, claramente, é que se encontra Na Maré Profuna, de Tabita Rezaire, ao invocar conhecimentos ancestrais relacionados à uma visão de mundo animista com referências como a arqueologia midiática da infraestrutura de cabos submarinos feita por Nicole Starosielski, através de uma estética pós-internet que nos convoca a decolonizar as infraestruturas.

Práticas artísticas como a de Tabita Rezaire produzem, assim, contranarrativas sobre as infraestruturas e, ao propor um imaginário de decolonização dessas, assumem um contra-futurismo decolonial infraestrutural. Trabalhos que realizam esse tipo de proposição, conforme Parikka (2018) indica em seu artigo sobre futurismos no imaginário árabe e africano, ajudam-nos a entender formas existentes de poder temporal e territorial a partir das tecnologias, assim como oferecem formas audiovisuais e narrativas que prescrevem um futuro pós-colonial para os tempos do porvir:

Desnecessário dizer, alguns desses futurismos imaginários lidam com uma diferente noção de tempo daquelas fornecidas pelos projetos de lluminismo Europeu reproduzidos e projetados através do espaço colonial planetário. As práticas audiovisuais de contrafuturismo, de passados situados e futuros inventivos que o Afrofuturismo nos fornece são também um contexto chave através do qual podemos nos aproximar do Oriente Médio e outros Futurismos. Também articulam uma 
política cultural do tempo, uma cronografia de poder. (PARIKKA, 2018, p. 3; trad. nossa)

Tal cronografia do poder consistiria em uma mobilização do tempo como uma força efetiva e ativa na esfera política contemporânea de expressões estéticas, criando povos imaginários e tempos por vir como parte de um tempo especificado em termos geográficos e étnicos, não linear e polifônico, imaginado, projetado e confuso. Algo próximo do que colocou Garuba como linguagem importante de ser gerada para lidar com uma forma de conhecimento que não exclui o ânimo das matérias.

Essa situação cronográfica se refere, principalmente, - e Parikka utiliza Rosi Braidotti para especificar isso - aos "despossuídos" do tropo modernista de tempo. Despossuídos de voz e subjetividade, o outro estrutural da modernidade. Com as mudanças climáticas antropogênicas e as ansiedades em torno da crise ecológica planetária, o futuro e seu cancelamento se tornam um tema central no horizonte das políticas étnicas, de raça e neoliberais, assim como nos trabalhos de arte, conforme Parikka, articula-se uma forma ativa e complexa de responder aos regimes existentes de tempo, poder e imaginário:

Torna-se um caminho para se oferecer uma contranarrativa de modernidade que começa com esse deslocamento na passagem transformadora do Atlântico Negro. Articula memória histórica através de práticas como a ficção científica enquanto também estabelece relações com, por exemplo, os movimentos gay e de mulheres, [...] Tais práticas formam, nas narrativas e audiovisualidades, espaços e temporalidades alternativas. As vezes, discursos sobre mídias imaginárias e práticas de arte/design são definidas como intempestivas, mas seria mais útil as considerar como forças ativas que podem enlouquecer os esquemas temporais existentes e complexificar os regimes de tempo já existentes como forma de poder. Como coloca Zielinski, 'todas as técnicas para reproduzir mundos existentes e criar novos mundos são, em um sentido específico, mídias temporais [time media] (2006: 31). Ou para dizer de outro modo, a criação da realidade (ou o que alguns chamariam de ideologia) é fundamentalmente relacionada com modalidades de tempo. E essas modalidades de tempo tanto como infraestrutura técnica quanto conforme circulam e condicionam essa experiência também na cultura popular e na arte contemporânea (PARIKKA, 2018, p. 5; trad. livre).

As águas oceânicas não esqueceram, para Rezaire, que as mesmas rotas que os cabos submarinos percorrem atualmente e que possibilitam a Internet foram utilizadas para o tráfico de negros, o que permitiu à Europa se estruturar em termos de produção econômica, científica e cultural para a modernidade. Na Maré Profunda nos oferece uma contranarrativa das tecnologias de comunicação que circulam através da água.

A obra invoca a ideia de "cura decolonial", refletindo sobre a infraestrutura da Internet a cruzar as águas oceânicas e levar informação 
em forma de luz. Nessas águas se encontram, como vimos no decorrer do tópico, diversas questões que podem afetar diretamente nossos modos de conhecer sobre as mídias: alteridades radicais, como sereias e criaturas tentaculares, moléculas que se comunicam e possuem memórias dos corpos negros que foram despejados durante as travessias atlânticas.

\section{Um olhar decolonial sobre a Internet e sua infraestrutura}

Nesta última sessão, trata-se de discutir relações entre infraestrutura e colonialismo em Na Maré Profunda, aproveitando a ocasião para também trazer alguns conceitos relevantes para o campo de estudos críticos sobre infraestrutura das mídias. Em tal campo, infraestrutura é mais do que um local ou objeto material organizado para produzir um sistema disperso, integrado e amplo de distribuição material de valor. Essa compreensão se restringe a um entendimento do que são infraestruturas físicas, mas infraestrutura em si é um conceito mais amplo, conforme Lisa Parks (2014, n.p.).

Afinal, infraestrutura é uma noção eminentemente relacional e lida não meramente com instalações físicas, mas com uma diversidade de relações ambientais, sócio-técnicas, que, no geral, encontram-se pouco enquadradas como objetos de investigações críticas no campo das Humanidades. O argumento geral de Parks, que já desenvolveu trabalhos em países como Zâmbia, Tanzânia e Rwanda, é de que é necessário, por um lado,

um imaginar mais amplo de afetos infraestruturais - experiências, sensações, declarações pessoais, estruturas de sentimento - gerados através do encontro material das pessoas com infraestruturas midiáticas (não só interfaces mas sítios físicos, instalações, dependências, hardware), enquanto, por outro lado, há uma necessidade de uma crítica contínua dos modos os quais o afeto continua a servir como parte de operações infraestruturais das mídias (PARKS, 2014, n.p.).

Comumente e no geral, sente-se apatia, indiferença e desinteresse por infraestruturas, mas a autora acredita que, por certas questões não terem sido postas, pode haver um amplo espectro de afetos infraestruturais não ditos e desconhecidos. Isso constituiria, por um lado, um imaginário que retira as infraestruturas do comportamento normalizado que as transforma em invisíveis. Por outro lado, explora o potencial de se romper com essa normalização. Afetar, na linha de pensamento referenciada por Parks, seria estabelecer relações de força moduladas em ritmos e 
modalidades crescentes e decrescentes de encontro, sensação e sensibilidade (PARKS, 2014, n.p.).

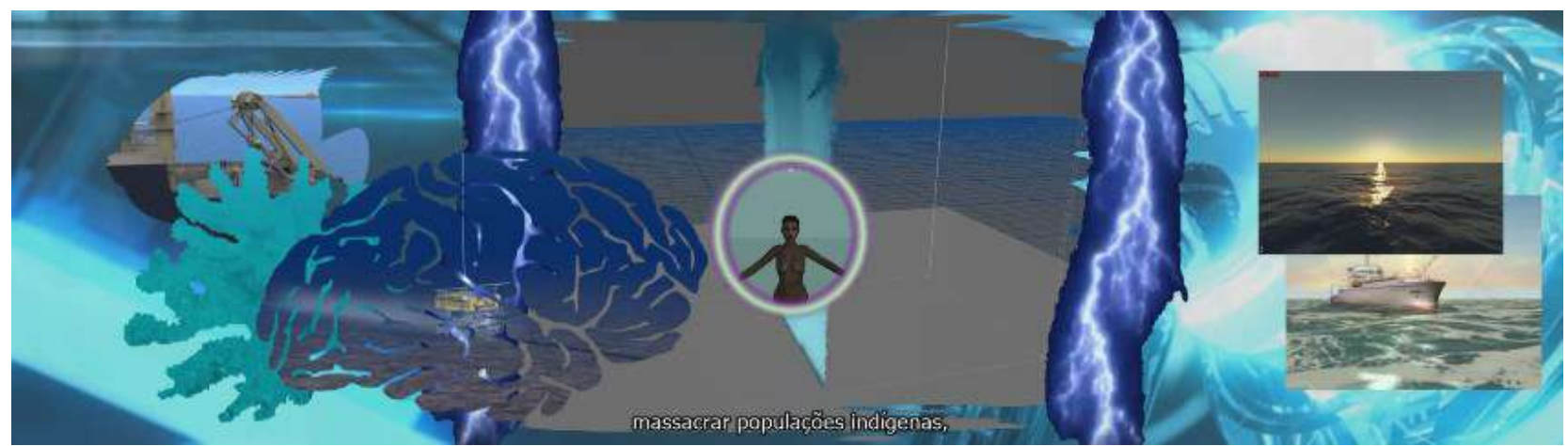

Figura 3 Cremos que a mobilização de imaginação, pensamento e troca de Frame de Na Maré Profunda. Fonte: Cortesia da Artista informações sobre infraestrutura que encontramos em Na Maré Profunda pode afetar a forma pela qual seu público passa a imaginar os cabos submarinos e sua infraestrutura a partir de alteridades não invocadas tradicionalmente no discurso entusiasmado da tecnofilia. Produz-se, assim, uma inteligibilidade infraestrutural situada na problematização das lógicas coloniais que se perpetuam do espaço on-line para a materialidade fisicamente operativa da Internet, em uma continuidade do projeto moderno de colonialismo. Esse projeto se torna visível tanto na sobreposição de rotas marítimas escravagistas por rotas infraestruturais de telecomunicação quanto no interesse de corporações como Google e Facebook em dominar o mercado africano através da Internet.

O seguinte texto vai aparecendo, em Na Maré Profunda, enquanto vemos imagens sobrepostas de profundezas oceânicas digitais; formas de peixes, cérebro e algas mascarando 6 imagens didáticas, apropriadas do Youtube, sobre como se instalam cabos submarinos; imagens digitalmente produzidas de armas douradas, cocaína e garrafas de álcool; mapas de rotas de cabos submarinos e rotas escravagistas; uma mulher negra desnuda; raios; cascatas; caravelas e tubarões:

\footnotetext{
6 Os editores de imagem digital oferecem a técnica de "máscara" para se selecionar áreas de uma imagem e confinar mudanças à essa área, permitindo que, como no caso aqui, se insiram vídeos na área confinada.
} 
Os perpetuadores da escravidão e do colonialismo tentaram (e ainda tentam) se defender e se justificar com a retórica da missão civilizacional: "Trouxemos cultura e modernidade para os selvagens", fingindo que suas novas rotas comerciais estavam conectando o Novo Mundo. Na realidade, tudo que fizeram foi roubar a terra, massacrar populações indígenas, explorar recursos e força de trabalho para ampliar a riqueza dos Impérios. O mesmo acontece com a Internet; gigantes da multimídia afirmam: "estamos conectando as pessoas umas com as outras", enquanto, por baixo dos panos, roubam e exploram nossos dados, nosso trabalho livre para ampliar sua riqueza e o poder de seus impérios de mídia. (REZAIRE, 2017; trad. livre)

A Internet atualmente se movimenta economicamente a partir dos dados e resíduos gerados pelos usuários, que têm seus hábitos de consumo analisados para assim serem vendidos a grandes empresas como potenciais clientes. $\mathrm{Na}$ economia da rede contemporânea, o conteúdo não é tão relevante quanto a proliferação e a agregação dos dados que os algoritmos das corporações midiáticas recombinam infinitamente para descobrir os gostos e os hábitos dos usuários, vendendo tais informações a terceiros, em uma reestruturação do capital a partir da abstração do valor afetivo dos dados. É daí que emerge, por exemplo, o conceito de trabalho afetivo, relacionado às críticas ao modo em que o capitalismo tardio passa a incorporar formas de trabalho "imaterial" e "invisível" e envolvendo habilidades sociais, serviços, consumo de dados - um processo que, ainda que tenha uma roupagem contemporânea e com camadas de digitalidade, não é novo:

Eu argumento que o uso do trabalho imaterial para sustentar as infraestruturas midiáticas é um processo histórico e pré-digital que data pelo menos ao período de emergência da telegrafia no meio do século XIX. O que nós temos na atual conjuntura histórica é uma demanda intensificadora por trabalho imaterial conforme as sociedades industriais mudaram de uma infraestrutura telecomunicacional telegrafia - para uma ordem pós-industrial em que múltiplas infraestruturas midiáticas - telefonia, rádio, televisão, cabo, satélite, Internet e telefonia móvel - cooperam e competem pelo tempo do usuário, sua atenção e energia. (PARKS, 2014, n.p., trad. livre)

A atual expansão da economia da Internet aponta a necessidade de se conquistar o que é chamado, conforme Parks, de O3B - "os outros três bilhões" que estão no planeta Terra sem acesso à Internet. Para a norteamericana, os planos de incluir pessoas pobres do sul global na Internet pode ser visto como um encobrimento para planos de expansão dos recursos humanos do capitalismo digital. A iniciativa do Facebook, por exemplo, de se aliar às empresas de telecomunicação para oferecer 
acesso grátis aos seus aplicativos é apontada por alguns como problemática, por dar prioridade aos conteúdos e dados transmitidos pela rede social californiana e associados. Com esse argumento, a iniciativa do Facebook foi banida na Índia, ao contrário da África, onde foi largamente aceita (MARZAL, 2016, n.p.).

Antes dessa questão se manifestar enquanto fenômeno dado nessa segunda década do século XXI, todavia, ainda em 1995, quando a Internet comercial começava a sua disseminação mais no Norte global, Ziauddin Sardar (citado por Rezaire na videoinstalação) escreveu seu ensaio sobre o ciberespaço o apontando como "o lado sombrio do Ocidente", a nova fronteira da colonização.

Mas a noção de uma nova fronteira é uma formulação mítica, construída para trazer o passado em uma unidade organizada e reinterpretada com o presente, enfatizando como o novo "território" está para ser dominado e controlado no futuro. A ocupação do ciberespaço tem paralelos diretos com a colonização de culturas não Ocidentais. O ciberespaço está se tornando o novo Outro das civilizações ocidentais que projetam todos os seus preconceitos coloniais no enquadramento das culturas não Ocidentais em imagens de sexo e violência do ciberespaço. (SARDAR, 1995, p. 777; trad. livre)

25 anos depois, a aposta de Rezaire é de que por meio de práticas de cura se pode encontrar formas de combater esse modo de colonialismo: essa cura envolve entender o conhecimento e suas fontes, buscando diferentes fontes e diferentes formas de receber e compartilhar informação; envolve reconhecer diversos meios, interfaces e tecnologias de comunicação; envolve um maior engajamento com as tecnologias presentes em nossos próprios corpos; envolve atuar de modo interseccional a partir de uma diversidade de identidades marginalizadas e oprimidas: negros, transgêneros, queers, macumbeiros e curandeiros. De maneira que podemos dizer que, a partir de sua perspectiva, o imaginário da tecnologia de comunicação digital é um imaginário onde também se delineia uma certa batalha de ânimos.

A abordagem de Rezaire não parece se encaixar exatamente no que Felinto (2003) discute como gnosticismo tecnológico, que repousa sobre o dualismo mente e corpo, tendencioso à uma lógica desmaterializante associada a um certo imaginário presente nos discursos sobre o virtual e o ciberespaço nos anos 1990 e começo dos anos 2000 e que buscam uma transcendência da condição humana através da tecnologia.

A gnose era uma religião elitista e excludente, e a nova tecnoreligião corre o risco de repetir esses seus traços fundamentais. Muito comum nos discursos ciberutópicos é 
o louvor das mutações extraordinárias que as novas tecnologias de informação e comunicação irão trazer à humanidade, mas também o quase total esquecimento de que essas transformações estão hoje ao alcance de uma parcela mínima da população mundial. (FELINTO, 2003, n.p.)

Rezaire se fundamenta em uma abordagem na qual a materialidade dos objetos e dos elementos são reconhecidos enquanto agentes, dotados de ânimo, isto é, de uma animação vitalizante, provendo a atividade e os sentidos vitais à percepção e à comunicação, sem se tratar de algo como alma, espírito ou consciência humana, mas de ânimo enquanto base de uma epistemologia relacional.

Tal epistemologia descreve os valores do animismo na habilidade de intercomunicação entre diversos elementos, um relacionamento interdependente com o mundo material, o qual inclui mesmo as infraestruturas de telecomunicação e a própria arquitetura da rede digital. Em alguns aspectos, converge e pode ser o sintoma de algo próximo ao que Felinto (2018b, p. 160) chama de "virada objetual [...] propugnada por vários autores nos mais diferentes fronts intelectuais"

Na Alemanha, por exemplo, a coleção de ensaios intitulada Die Wiederkehr der Dinge (O retorno das coisas, 2011), assim como o pequeno livro de Dorothee Kimmich, Lebendige Dinge in der Moderne (Coisas vivas na modernidade, 2011), e a coletânea Cinematographic objects (2015) dão testemunho da curiosidade contemporânea em relação aos objetos. Em certo sentido, essas abordagens respondem ao apelo, feito por Hans Ulrich Gumbrecht já em 1994, por teorias que possam integrar "formas de auto-referência humanas" que sejam "menos antropocêntricas", "menos anti-tecnológicas" e "menos transcendentais" (1994, p. 392). (FELINTO, 2018b)

A genealogia do pensamento articulado por Rezaire, todavia, inclui diretamente a influência de sua ancestralidade africana e um desejo de produzir uma diversidade maior de olhares desde essa ancestralidade para a posição que a África pode ter em questões envolvendo mídia e tecnologia na contemporaneidade. Em outros termos, seu trabalho nos provoca a pensar como as tecnologias de comunicação, digitais ou não, são percebidas, desafiadas e afetadas pelas culturas africanas, históricas ou contemporâneas. Isso envolve, como falado reiteradamente por Rezaire, questões relacionadas aos sistemas de conhecimento, pré ou pós-coloniais, e a exploração de como diferentes culturas desdobram distintos modos de engajamento com as tecnologias. 


\section{Conclusão}

Destacou-se, no presente artigo, poucos trechos da obra Na Maré Profunda, mas tais fragmentos continham elementos suficientes para suscitar discussões que agruparam pensadores em um encontro ainda pouco usual entre infraestrutura, tecnologia, mídia, animismo e arte, atravessados por uma linha comum: epistemologia.

Diversos fenômenos que se manifestam contemporaneamente envolvendo práticas tecnológicas apresentam desafios para os modos de conhecimento calcificados na pedra fundamental do racionalismo científico: se entrecruzam por entre diferentes áreas, modulando nelas crises de incapacidade e identidade diante do espelho da especificidade. Não é que isso seja algo novo, mas certas discussões atualizam o drama.

Cremos que é no território das africanidades que estão se dando os fenômenos mais singularmente intensos e mágicos no contexto tecnodigital da contemporaneidade. Fenômenos infelizmente ainda muito invisibilizados, não discutidos e pouco disseminados nos campos de produção do conhecimento. Essa invisibilidade, na verdade, é sintomática dos atritos que a compreensão científica do que é conhecimento encontra quando pisa na África.

Brestow, no texto curatorial da exposição Post-African Futures (Joanesburgo - 2015), afirma que a falta de alcance do conhecimento sobre como a África está posicionada em termos de tecnologias midiáticas gera dois problemas: por um lado, nega as consequências da realização do neocolonialismo através de tecnologias comunicacionais e por outro lado presume que não existem histórias únicas e regionais sobre tecnologia. Nesse contexto, pouca atenção se dá para as questões socioculturais, epistemológicas ou filosóficas dos sistemas técnicos que emergem nas práticas não ocidentais com tecnologia, mídia e arte.

Há quem, no meio complexo do sistema de arte, encontre formas de modular encontros entre diversos sistemas de conhecimento e, assim, desdobre a própria arte enquanto tal. Enquanto os acadêmicos estritos ainda se encontram bastante limitados à linearidade e a escrita para gerarem conhecimento, os artistas podem estar à vontade para ensejar o conhecer através do escrever, mas também do espacializar, do imaginar, do criar, do performar, do curar. Um dos aspectos mais significativos do trabalho de Rezaire, poder-se-ia dizer, está na consciência de que a arte pode ser um sistema de conhecimento aberto ao envolvimento direto com outros sistemas de conhecimento: o acadêmico, o ancestral, o técnico. 
Encontra-se a potência da reflexão, assim, em uma zona tão cinzenta e animada como o é o próprio oceano. Refletindo-se a partir de um corpo negro, inevitavelmente vozes ancestrais se manifestarão lembrando que a experiência corporificada da navegação, para o negro, é repleta de cicatrizes e feridas, que ainda se manifestam na navegação on-line, quando algoritmos evidenciam como programadores codificam sem escapar de racializarem, genderizarem e cistematizarem, como fizeram, até há algumas décadas atrás, colonos em territórios africanos.

Nesse contexto, artistas, arqueólogos da mídia, poetas, engenheiros, biólogos marinhos vão encontrando convergências para invocar outras concepções e modos de se relacionar com as matérias, os espaços e o tempo para além de binarismos estruturantes do pensamento moderno. Parikka nos fala da emergência, nesse contexto, de contra-narrativas e contra-futurismos; Cláudio Bueno e Lígia Nobre falaram de contrafeitiçarias no texto curatorial da exposição que convidou Rezaire ao Brasil. Contra-gestos que, assim, podem exercitar o decolonial, ou pelo menos, epistemologias midiáticas e tecnológicas mais pluralmente situadas. 


\section{Referências}

BORCK, Cornelius. Animism in the Sciences Then and Now. e-flux Journal \#36. 2012. Disponível em: [https://www.eflux.com/journal/36/61266/animism-in-the-sciences-then-and-now/]. Acessado em 15 de julho de 2019.

BRAUN, Leslie. Cyber Siren: What Mami Wata reveals about the Internet and Chinese presence in Kinshasa. Canadian Journal of African Studies/La Revue canadienne des études africaines. 2015

BRISTOW, Tegan. Post African futures: positioning the globalized digital within contemporary African cultural and decolonizing practices. Critical African Studies,

Vol. 9, No. 3, 281-301. 2017

CHRISTOU, Elisavet e HAZAS, Michael David. It's Just the Internet! Appropriation in Postinternet Art. / Christou, Elisavet; Hazas, Michael David. ARTECH2017 Proceedings of the 8th International Conference on Digital Arts. Macau : ACM, 2017. p. 127-133. 2017

HELMREICH, Stefan. Alien ocean: Anthropological voyages in microbial seas. Univ of California Press, 2009

FELINTO, Erick. Oceano digital: imaginário marinho, tecnologia e identidade em Vilém Flusser. Galaxia (São Paulo, online), ISSN 19822553, n. 39, set-dez., p. 110-123. 2018.

, Realismo especulativo, comunicação e a lula-vampiro do inferno. In: Dossiê Realismo Especulativo. Revista Eco-Pós. V. 21, n. 2. $2018 b$

- A Religião das Máquinas: pressupostos metodológicos para uma investigação do imaginário da cibercultura. Anais Compós. 2003.

GARUBA, Harry. On Animism, Modernity/Colonialism, and the African Order of Knowledge: Provisional Reflections. e-flux Journal \#36. 2012

KRÖPLIN, Bernd. HENSCHEL, Regine. Die Geheimnisse des Wassers: Neueste erstaunliche Ergebnisse aus der Wasserforshung. AT Verlag. Aarau und München. 2016

MARZAL, Andrew. Facebook Dragged into 'colonialism' row in India. In: The Telegraph Online. 2016 Disponível em: 
[https://www.telegraph.co.uk/news/worldnews/asia/india/12150278 /Facebook-dragged-into-colonialism-row-in-India.html]. Acessado em 12 de julho de 2019.

NAVEH, D. \& BIRD-DAVID, N. On Animisms, conservation and Immediacy. In: A handbook on contemporary animism. Harvey G. Ed. Durham: Acumen Publishing, pp. 27-37. 2013

PARIKKA, Jussi. A geology of media. Electronic Mediations, vol. 46. University of Minnesota Press. 2015

Middle East and other futurisms: imaginary temporalities in contemporary art and visual culture. In: Journal Culture, Theory and Critique. Vol. 59, Issue 1. Pp. 40-58. 2018

PARKS, Lisa. Media Infrastructures and Affect. Flow TV, 19, no. 12. 2014. Disponível em: [http://flowtv.org/2014/05/media-infrastructures-andaffect/]. Acessado em 13 de junho de 2018.

PETERS, John Durham. Marvelous Clouds: Towards a philosophy of elemental media. University of Chicago Press. 2015

PECKHAM, Robin and Karen Archey, Art Post-Internet. Art Post-Internet, October 14, 8-9., 2014. Disponível em: [http://post-inter.net]. Acessado em 12 de julho de 2019.

SARDAR, alt.civilization.faq: cyberspace as the darker side of the west. In Z. Sardar and J. R. Ravets (Eds.) Cyberfutures: culture and politica on the information superhighway (pp. 14-41) New York: New York University Press. 1995

SCHMITT, C. The Nomos of the Earth. New York: Telos Press, 2006.

SIEGERT, Bernhard. Passage des Digitalen. Zeichenpraktiken der neuzeitlichen Wissenschaften. Berlin: Brinkmann \& Bose, 2003.

STAROSIELSKI, Nicole. The Undersea Network. Duke University Press. 2015.

STEYERL, Hito. Too much world: Is the Internet dead?. E-flux journal, v. 49, 2013. 


\section{REFERÊNCIAS AUDIOVISUAIS}

REZAIRE, Tabita. Deep Down Tidal. Goodman Gallery. Johannesburg. 2017.

Cura descolonial: tecnologia, espiritualidade e o erótico. Sesc Belenzinho. São Paulo. 2018. 